Original paper

\title{
Hepatocyte growth factor and epidermal growth factor activity during later stages of rat liver regeneration upon interferon $\alpha-2 b$ influence
}

\author{
Brygida Adamek1, Marzena Zalewska-Ziob², Joanna K. Strzelczyk², Janusz Kasperczyk³, Kinga Wołkowska-Pokrywa², \\ Grażyna Spaustaㄹ Edyta Hudziec ${ }^{4}$, Andrzej Wiczkowski ${ }^{5}$, Elżbieta Świętochowska², Michał Kukla ${ }^{6}$, Zofia Ostrowska ${ }^{2}$ \\ 'Department of Basic Medical Sciences, Medical University of Silesia, Katowice, Poland \\ 2Department of Medical and Molecular Biology, Medical University of Silesia, Katowice, Poland \\ ${ }^{3}$ Department of Environmental Medicine and Epidemiology, Medical University of Silesia, Katowice, Poland \\ ${ }^{4}$ Department of Biochemistry, Medical University of Silesia, Katowice, Poland \\ ${ }^{5}$ Department of Nursing and Emergency Medicine, Faculty of Health Sciences, University of Bielsko-Biała, Poland \\ ${ }^{6}$ Department of Gastroenterology and Hepatology, Medical University of Silesia, Katowice, Poland
}

\begin{abstract}
Introduction: Liver regeneration is a complex, highly coordinated process which can be disturbed by the impact of the anti-proliferative interferon $\alpha$ activity. In the model of partial hepatectomy $(\mathrm{PH})$ in the rat the expression of HGF and EGF genes and their molecules' tissue concentrations were analyzed in the later stages of liver regeneration (48-120 h).

Material and methods: 40 three-month-old male Wistar rats were randomized to groups of 20 animals each. The rats of the study group (IFN/H) were injected subcutaneously with IFN $\alpha-2 b$, while the control group was injected with $0.5 \mathrm{ml}$ of $0.9 \% \mathrm{NaCl}(\mathrm{NaCl} / \mathrm{H})$. In the liver tissue samples obtained during hepatectomy and autopsy (regenerating liver mass) the expression of HGF and EGF genes was estimated with the Q-PCR method and the analysis of HGF and EGF molecule concentrations in tissue homogenates was conducted with the ELISA method. Results: HGF but not EGF expression was significantly higher at $48 \mathrm{~h}$ after PH, while EGF expression was higher in normal than in regenerating liver tissue at $120 \mathrm{~h}$. The analyses of correlations between expression of HGF and EGF in regenerating liver tissue, both normal and upon IFN $\alpha-2 b$ influence, together with correlations between those factors genes' expression and HGF and EGF tissue concentrations in analyzed samples, showed no significant differences.

Conclusions: HGF and EGF are not significantly involved in regulation of later stages of rat liver regeneration. IFN $\alpha-2 b$ does not impact expression of their genes or the presence of these growth factor molecules in regenerating liver tissue.
\end{abstract}

Key words: hepatocyte growth factor (HGF), epidermal growth factor (EGF), interferon $\alpha-2 b$ (IFN $\alpha-2 b)$, partial hepatectomy (PH), rat liver regeneration.

Address for correspondence

Marzena Zalewska-Ziob, Department of Medical and Molecular Biology, Medical University of Silesia, 19 Jordana St., 41-808 Zabrze, Poland, phone/fax: +48 3227221 71, e-mail: mirabilis18@wp.pl

\section{Introduction}

Liver regeneration after the loss of hepatic tissue is a fundamental liver response to injury [1]. In the rat the removal of median and left lateral lobes (about $70 \%$ of liver mass) results in the organ rebuilding within 7-10 days [2]. In this commonly used rat model of partial hepatectomy $(\mathrm{PH})$ hepatocytes divide first at about $24 \mathrm{~h}$ after hepatectomy, followed by the biliary ductular cells, then the Kupffer cells and stellate cells, and finally 
the endothelial cells $[1,3]$. This highly coordinated process is regulated by three main types of pathways, including cytokines and growth factors, changes in enzymes and proteins related to the extracellular matrix (ECM), and metabolic networks that link liver function with cell growth and proliferation $[3,4]$. In the set of growth factors the hepatocyte growth factor (HGF) and epidermal growth factor (EGF) appear to play important roles in this process $[1,5]$. Hepatocyte growth factor, up-regulated in response to liver injury, acts as a ligand of the c-Met proto-oncogene product, which is expressed not only on hepatocytes but also on endothelial and epithelial cells [6]. Epidermal growth factor acts via epidermal growth factor receptor (EGFR), inducing DNA synthesis in rat hepatocytes [7, 8]. Both c-met and EGFR are transmembrane tyrosine kinases, which while interacting with their ligands start the cascade of phosphorylations resulting in the activation of transcription factors $[4,9]$. The role of HGF and EGF in the priming and early stage of liver regeneration is well established [3-5], but it is not clear whether their activity is also important in later phases of that organ's rebuilding, especially upon the influence of factors with anti-proliferative potential.

Type I interferons are pleiotropic cytokines identified over 50 years ago, and it is stated that they inhibit the transcription and/or translation of a number of

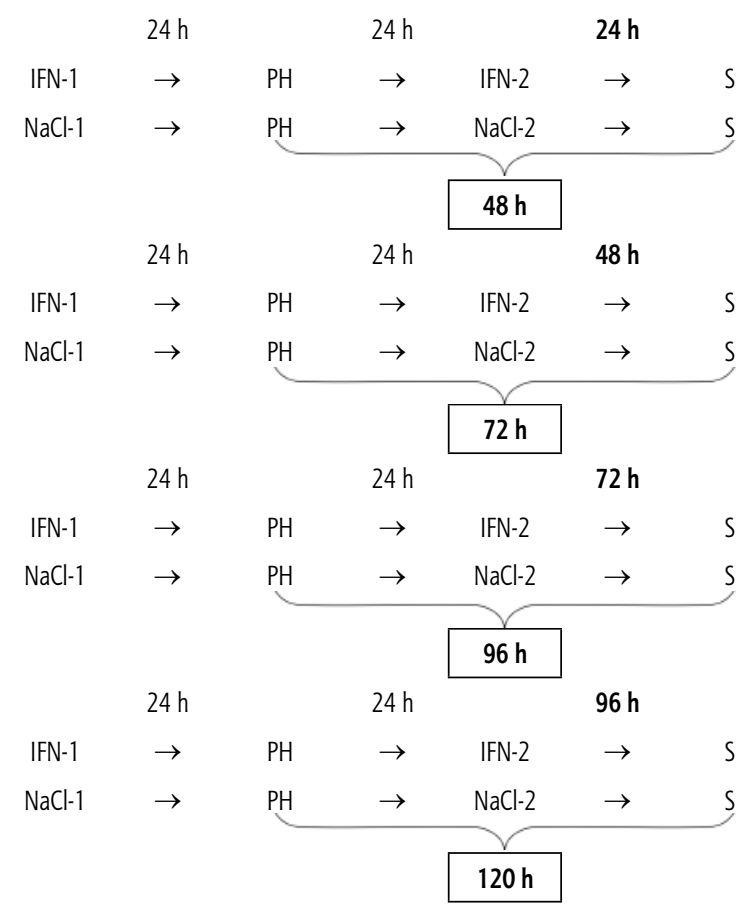

IFN-1 - first dose of IFN- $\alpha 2 b$ administration, IFN-2 - second dose of IFN $\alpha-2 b$ administration, NaCl-1 - first dose of saline administration, $\mathrm{NaCl}-2$ - second dose of saline administration, $\mathrm{PH}$ - partial (70\%) hepatectomy, S - scarification

Fig. 1. Schedule of animal experiment
RNA and DNA viruses, as well as the growth and proliferation of a variety of cell types $[10,11]$. Interacting with their specific receptor they activate classical JAK (Janus kinase)-STAT (signal transducer and activator of transcription) signaling pathways and regulate, either directly or indirectly, several other downstream cascades [12].

According to our best knowledge, the influence of IFN- $\alpha$ on growth factors, namely HGF and EGF, during late stages of rat liver regeneration has not been explored. We used a $\mathrm{PH}$-induced liver regeneration rat model to investigate the influence of IFN- $\alpha$ administration on expression of the HGF and EGF genes together with the concentrations of HGF and EGF molecules in liver tissue until $120 \mathrm{~h}$ after surgery.

\section{Material and methods}

The 40 three-month-old male Wistar rats were maintained on rat chow and water under standard conditions. Animals were randomly assigned to groups of 20 rats each. The animals of the first group (IFN/H) were injected subcutaneously with $0.5 \mathrm{ml}$ of IFNa-2b (Intron A, Shering-Plough, $5 \mathrm{MU} / 100 \mathrm{ml} 0.9 \% \mathrm{NaCl}$ ). $24 \mathrm{~h}$ later the $3 / 4$ (70\%) partial hepatectomy was performed according to Higgins and Anderson under anesthesia (ketamine intraperitoneally, $50 \mathrm{mg} / \mathrm{kg}$ ) by removing the median and left lateral lobes [2]. After the next $24 \mathrm{~h}$ the second IFNa-2b dose was administered. A similar schedule was applied in the next group injected with $0.5 \mathrm{ml}$ of $0.9 \% \mathrm{NaCl}(\mathrm{NaCl} / \mathrm{H}$, control group). Rats were sacrificed in groups of five at $48 \mathrm{~h}$, $72 \mathrm{~h}, 96 \mathrm{~h}$ and $120 \mathrm{~h}$ after surgery. Injections and surgical procedures were carried out between 9.00 and 11.00 a.m. to minimize the influence of circadian variations. Excised livers samples (in IFN/H and $\mathrm{NaCl} / \mathrm{H}$ groups, obtained during hepatectomy, marked "1"), and restituted liver mass (in IFN/H and $\mathrm{NaCl} / \mathrm{H}$ groups, obtained during autopsy, marked "2") were divided into two separate portions and stored at $-80^{\circ} \mathrm{C}$. The experiment schedule is shown in Figure 1.

The study protocol conformed to the ethical guidelines of the 1975 Declaration of Helsinki, as reflected by the a priori approval (no. 1/02; 19.02.2002) of the Local Ethics Commission for Animal Experiments of the Medical University of Silesia.

Total RNA was isolated from $80 \mathrm{mg}$ of tissue samples using the RNeasy Midi Kit (Qiagen, Germany). In addition to the standard procedure, DNase I (Qiagen, Germany) was used to remove trace amounts of genomic DNA. RNA were quantified by measuring the absorbance at 260 and $280 \mathrm{~nm}$ and the integrity was assessed by electrophoresis in ethidium bromide stained 
$1.2 \%$ agarose gel. RNA isolates were used for cDNA synthesis by RT reaction. $1 \mu \mathrm{g}$ of total RNA was reverse transcribed into cDNA in a total volume of $100 \mu \mathrm{l}$ using the High-Capacity cDNA Archive Kit (Applied Biosystems, USA) according to the manufacturer's instructions. Obtained CDNA was used to determine $H G F$ and $E G F$ gene expression levels by quantitative real-time PCR assay (TaqMan system). TaqMan primers and probes for HGF and EGF were bought as ready to use TaqMan Gene Expression Assays (Rn 00566673_m1 and Rn 00563336_ml, respectively) and for the housekeeping gene - GAPDH Endogenous Control (FAM/ MGB Probe, Primer Limited, Rn 99999916_s1) (Applied Biosystems, USA). Q-PCR for both genes was performed in a volume of $20 \mu$ lon the ABI PRISM 7300 Real Time PCR Detection System (Applied Biosystems, USA). For each run, a Q-PCR mix was prepared on ice containing $10 \mu \mathrm{l}$ of Applied Biosystems Universal PCR Master Mix, $1 \mu \mathrm{l}$ of primers and probe mix and $8 \mu \mathrm{l}$ of $\mathrm{H}_{2} \mathrm{O}$ (Qiagen, Germany). To each well of a 96-well plate, $19 \mu \mathrm{l}$ of Q-PCR mix and $1 \mu \mathrm{l}$ of cDNA samples were added. All PCRs were performed in triplicate. In all amplification reactions, a negative control was also included. Thermal cycling for HGF, EGF and GAPDH genes was initiated with an incubation step at $50^{\circ} \mathrm{C}$ for 2 minutes, followed by a first denaturation step at $95^{\circ} \mathrm{C}$ for 10 minutes, and continued with 40 cycles of $95^{\circ} \mathrm{C}$ for 15 seconds, $60^{\circ} \mathrm{C}$ for 1 minute. The standard curves for the housekeeping gene GAPDH and the target genes were generated by serial dilutions of the control cDNA (equivalent to $1 \mu \mathrm{g}$ of total RNA) in six 2 -fold dilution steps. The expression levels of HGF, EGF and $G A P D H$ genes in every sample were determined from the respective standard curve and the analyzed genes' expression was divided by the GAPDH gene expression to obtain a normalized target value (relative expression level).

Weighed samples of rat liver (100 mg) were homogenized using a PRO 200 homogenizer (PRO Scientific Inc, USA) at 10000 RPM in nine volumes of phosphate-buffered saline solution (PBS without $\mathrm{Ca}$ and Mg, BIOMED, Poland) containing 0.5\% Triton X-100 (Sigma-Aldrich, USA). Next homogenates were centrifuged at $12000 \mathrm{RPM}$ for 15 minutes at $+4^{\circ} \mathrm{C}$, and the supernatants were divided into appropriate portions and frozen at $-80^{\circ} \mathrm{C}$ until required for further surveys. Total protein concentration in the liver tissue homogenates was determined with the Lowry method. In this method, the final color is of two reactions: first the biuret reaction with $\mathrm{Cu}^{2+}$ ions in an alkaline medium, then the second reaction reducing phosphomolybdic and phosphowolframic acid (Folin-Ciocalteu reagent) to the corresponding oxides by tyrosine and tryptophan present in the proteins [13]. Hepatocyte growth factor and EGF concentrations in the rat liver tissue homogenates were measured with ELISA methods using the HGF ELISA kit (cat. no. SEA047Ra Cloud - Clone, USA) and EGF ELISA Kit (cat. no. SEA560Ra, Cloud - Clone, USA) according to the manufacturer's instructions. The absorption values were read at $450 \mathrm{~nm}$ in a microplate reader ( $\mu$ Quant, BIO-TEK INSTRUMENTS, INC, USA) with KC Junior software (BIO-TEK, USA). Concentrations were estimated according to the respective standard curves, taking into account the 50 -fold dilution of specimens. The results were calculated in $\mathrm{pg} / \mathrm{mg}(\mathrm{ng} / \mathrm{g})$ total protein concentration for every tissue sample (relative concentration). The measurements were conducted in duplicate, with estimated variation of $4.2-14.8 \%$ for HGF and $0.4-6.0 \%$ for EGF.

Data were analyzed using the Statistica 10.0 software pack. Descriptive statistics were calculated and data were tested for normality of distribution and homogeneity of variance. For differences between groups in the case of independent samples the analysis of variance and post hoc tests while for dependent variables $t$ tests for dependent samples were used, with $p<0.05$ considered significant. The direction and strength of the dependence between quantitative variables was evaluated by use of the regression equation and linear correlation coefficient.

\section{Results}

The schedule of our experiment allowed us to analyze the $H G F$ and $E G F$ expression together with HGF and EGF tissue concentrations in normal liver, the liver exposed to a single dose of IFNa-2b, normal regenerating liver tissue and the liver regenerating upon IFNa-2b influence at consecutive time points. Results of these analyses are presented in Table 1 - according to HGF - and Table 2 - according to EGF. HGF expression was significantly different at $48 \mathrm{~h}$ after $\mathrm{PH}$ : it was higher in regenerating rat liver, both normal and exposed to IFNa-2b. This phenomenon had no further consequences in higher HGF concentration in liver tissue at any analyzed time points and conditions (Table 1). In contrast, $E G F$ expression was not significantly different in liver exposed to IFNa-2b influence, but it was higher in normal liver compared with regenerating tissue only at $120 \mathrm{~h}$ after PH. No changes in EGF liver tissue concentrations were noted (Table 2). Because HGF and EGF concentrations were calculated based on liver tissue protein concentration, we analyzed this parameter in every study group, finding no differences (Table 3). 
Table 1. Expression of HGF gene and concentration of HGF in normal and regenerating liver tissue upon IFN $\alpha-2 b$ influence

\begin{tabular}{|c|c|c|c|c|c|c|}
\hline \multirow[b]{3}{*}{ Group } & \multicolumn{3}{|c|}{ HGF/GAPDH } & \multicolumn{3}{|c|}{ HGF [ng/g] } \\
\hline & "1" & "2" & & "1" & "2" & \\
\hline & $\begin{array}{l}\text { Liver upon } 1 \text { dose } \\
\text { of IFN } \alpha-2 b ; \\
\text { mean } \pm S D\end{array}$ & $\begin{array}{l}\text { Regenerating liver upon } \\
\text { IFN } \alpha-2 b \text { influence; } \\
\text { mean } \pm S D\end{array}$ & $p$ value & $\begin{array}{l}\text { Liver upon } 1 \text { dose } \\
\text { of IFN } \alpha-2 b ; \\
\text { mean } \pm S D\end{array}$ & $\begin{array}{l}\text { Regenerating liver upon } \\
\text { IFN } \alpha-2 b \text { influence; } \\
\text { mean } \pm S D\end{array}$ & $p$ value \\
\hline IFN/H/48 & $1.04 \pm 0.35$ & $2.71 \pm 0.40$ & 0.02 & $828.41 \pm 87.70$ & $865.71 \pm 230.18$ & 0.71 \\
\hline IFN/H/72 & $1.16 \pm 1.52$ & $1.49 \pm 1.78$ & 0.06 & $775.72 \pm 35.86$ & $1095.67 \pm 214.56$ & 0.24 \\
\hline IFN/H/96 & $0.37 \pm 0.14$ & $1.98 \pm 0.71$ & 0.07 & $874.96 \pm 186.56$ & $576.65 \pm 21.83$ & 0.09 \\
\hline \multirow[t]{2}{*}{ IFN/H/120 } & $1.97 \pm 2.99$ & $5.90 \pm 7.13$ & 0.16 & $737.46 \pm 91.57$ & $676.70 \pm 45.26$ & 0.20 \\
\hline & Normal liver - control & Regenerating liver - control & & Normal liver - control & Regenerating liver - control & \\
\hline $\mathrm{NaCl} / \mathrm{H} / 48$ & $0.50 \pm 0.44$ & $3.83 \pm 0.60$ & 0.02 & $781.71 \pm 8.45$ & $607.09 \pm 427.35$ & 0.67 \\
\hline $\mathrm{NaCl} / \mathrm{H} / 72$ & $0.06 \pm 0.04$ & $1.83 \pm 2.48$ & 0.50 & $700.95 \pm 60.28$ & $726.39 \pm 79.18$ & 0.32 \\
\hline $\mathrm{NaCl} / \mathrm{H} / 96$ & $0.34 \pm 0.05$ & $4.44 \pm 3.46$ & 0.18 & $829.87 \pm 235.55$ & $768.26 \pm 40.61$ & 0.65 \\
\hline $\mathrm{NaCl} / \mathrm{H} / 120$ & $3.10 \pm 1.37$ & $3.16 \pm 2.10$ & 0.92 & $735.05 \pm 52.72$ & $569.89 \pm 206.75$ & 0.10 \\
\hline
\end{tabular}

Table 2. Expression of EGF gene and concentration of EGF in normal and regenerating liver tissue upon IFN $\alpha$ - $2 \mathrm{~b}$ influence

\begin{tabular}{|c|c|c|c|c|c|c|}
\hline \multirow[b]{3}{*}{ Group } & \multicolumn{3}{|c|}{ EGF/GAPDH } & \multicolumn{3}{|c|}{$\mathrm{EGF}[\mathrm{ng} / \mathrm{g}]$} \\
\hline & "1" & "2" & & "1" & "2" & \\
\hline & $\begin{array}{l}\text { Liver upon } 1 \text { dose of } \\
\text { IFN- } \alpha 2 b ; \\
\text { mean } \pm \text { SD }\end{array}$ & $\begin{array}{l}\text { Regenerating liver upon } \\
\text { IFN- } \alpha 2 b \text { influence; } \\
\text { mean } \pm S D\end{array}$ & $p$ value & $\begin{array}{l}\text { Liver upon } 1 \text { dose of } \\
\text { IFN- } \alpha 2 b ; \\
\text { mean } \pm \text { SD }\end{array}$ & $\begin{array}{l}\text { Regenerating liver upon } \\
\text { IFN- } \alpha 2 b \text { influence; } \\
\text { mean } \pm S D\end{array}$ & $p$ value \\
\hline IFN/H/48 & $4.33 \pm 1.39$ & $3.08 \pm 1.87$ & 0.41 & $654.96 \pm 85.79$ & $488.98 \pm 94.86$ & 0.05 \\
\hline IFN/H/72 & $1.27 \pm 2.18$ & $2.31 \pm 3.25$ & 0.99 & $686.97 \pm 92.76$ & $741.09 \pm 95.59$ & 0.02 \\
\hline IFN/H/96 & $1.11 \pm 1.06$ & $6.11 \pm 9.61$ & 0.98 & $771.59 \pm 130.58$ & $413.71 \pm 15.86$ & 0.03 \\
\hline \multirow[t]{2}{*}{ IFN/H/120 } & $0.55 \pm 0.17$ & $2.32 \pm 2.26$ & 0.13 & $585.46 \pm 88.13$ & $507.2 \pm 30.32$ & 0.08 \\
\hline & Normal liver - control & Regenerating liver - control & & Normal liver - control & Regenerating liver - control & \\
\hline $\mathrm{NaCl} / \mathrm{H} / 48$ & $2.78 \pm 3.52$ & $9.08 \pm 3.74$ & 0.22 & $549.12 \pm 94.16$ & $507.02 \pm 455.96$ & 0.94 \\
\hline $\mathrm{NaCl} / \mathrm{H} / 72$ & $1.43 \pm 0.80$ & $3.19 \pm 1.05$ & 0.13 & $613.22 \pm 95.59$ & $483.13 \pm 70.26$ & 0.11 \\
\hline $\mathrm{NaCl} / \mathrm{H} / 96$ & $0.82 \pm 0.10$ & $1.26 \pm 1.15$ & 0.60 & $554.16 \pm 175.21$ & $596.44 \pm 59.49$ & 0.65 \\
\hline $\mathrm{NaCl} / \mathrm{H} / 120$ & $4.76 \pm 2.25$ & $2.37 \pm 1.65$ & 0.006 & $748.90 \pm 52.52$ & $563.56 \pm 203.05$ & 0.07 \\
\hline
\end{tabular}

"1" - liver tissues removed during partial hepatectomy

"2" - regenerating liver mass obtained during autopsy at consecutive time points

The correlation between $H G F$ and $E G F$ expression was significant in normal liver tissue (Fig. 2) and upon the impact of a single dose of IFNa-2b (Fig. 3). Despite these results, no correlations between HGF and EGF concentrations in normal or regenerating liver were observed. Similarly, there were no significant correlations between $H G F$ expression and HGF concentration as well as EGF expression and EGF concentration in regenerating liver tissue, and no influence of IFNa-2b was observed (data not shown).

\section{Discussion}

The nature of the lost liver tissue rebuilding, compensatory hyperplasia rather than true regeneration, has been explored for many years, but many aspects of this phenomenon are poorly understood $[14,15]$. The process of hepatocyte repopulation is accomplished by a sequence of distinct phases: an initiation phase, rendering cells in a state of replicative competence; a proliferation phase, where expansion of the cell 
Table 3. Protein concentration in the liver tissue specimens obtained during experiment

\begin{tabular}{|c|c|c|c|}
\hline \multirow[b]{3}{*}{ Group } & \multicolumn{3}{|c|}{ Total liver tissue protein [g/l] } \\
\hline & "1" & $" 2 "$ & \\
\hline & Liver upon 1 dose of IFN $\alpha-2 b$; mean \pm SD & Regenerating liver upon IFN $\alpha-2 b$ influence; mean \pm SD & $p$ value \\
\hline IFN/H/48 & $16.30 \pm 2.29$ & $13.60 \pm 0.57$ & 0.10 \\
\hline IFN/H/72 & $16.28 \pm 1.88$ & $14.20 \pm 1.41$ & 0.89 \\
\hline IFN/H/96 & $14.60 \pm 0.84$ & $14.83 \pm 2.15$ & 0.98 \\
\hline \multirow[t]{2}{*}{ IFN/H/120 } & $16.72 \pm 1.70$ & $16.58 \pm 1.00$ & 0.83 \\
\hline & Normal liver - control & Regenerating liver - control & \\
\hline $\mathrm{NaCl} / \mathrm{H} / 48$ & $17.10 \pm 1.18$ & $14.30 \pm 1.56$ & 0.33 \\
\hline $\mathrm{NaCl} / \mathrm{H} / 72$ & $16.50 \pm 1.18$ & $14.33 \pm 0.45$ & 0.15 \\
\hline $\mathrm{NaCl} / \mathrm{H} / 96$ & $16.82 \pm 1.43$ & $15.83 \pm 0.15$ & 0.81 \\
\hline $\mathrm{NaCl} / \mathrm{H} / 120$ & $17.26 \pm 2.47$ & $14.94 \pm 1.92$ & 0.10 \\
\hline
\end{tabular}

"1" - liver tissues removed during partial hepatectomy

"2" - regenerating liver mass obtained during autopsy at consecutive time points

population occurs; and a termination phase, where cell growth is suppressed to terminate regeneration at a set point $[16,17]$. In our experimental model we collected regenerating liver tissue at $48 \mathrm{~h}, 72 \mathrm{~h}, 96 \mathrm{~h}$ and $120 \mathrm{~h}$, i.e. we focused on proliferation and early termination phases. Administration of the first IFNa-2b dose 24 hours before $\mathrm{PH}$ created the possibility of its influence on molecular phenomena during the initiation phase. Hepatocyte growth factor and EGF, the complete mitogens for hepatocytes, are proven to play a role mainly in the initiation phase of liver regeneration [1, $3,8,18$. However, HGF is synthesized and excreted by mesenchymal cells diffused over the organs and tissues as a single-chain polypeptide and deposited in the ECM of the liver as an inactive precursor $[19,20]$. In basal conditions HGF mRNA and HGF are present in small amounts in liver tissue, but the early phenomenon just after injury is the release of HGF from ECM deposits and forming its active, double-chain molecule [21, 22] and then higher expression of $H G F$ in the remnant liver $[23,24]$. In our experiment IFNa-2b was administered twice, the first dose 24 hours before $\mathrm{PH}$ - which could reduce protein synthesis in resting hepatocytes and non-parenchymal liver cells and negatively regulate the priming phase, resulting in delayed regeneration as in the experiment by Nishiguchi et al. [25]. Theocharis et al. administered IFNa-2b either 2 or $12 \mathrm{~h}$ postoperatively, and inhibition of hepatocyte proliferation was observed at $24 \mathrm{~h}$ postoperatively, while at further time intervals up to $48 \mathrm{~h}$ DNA synthesis remained similar to that observed in the control group [26]. It could suggest that IFNa-2b-influenced inhibition of regeneration progress lasts around 24-48 $\mathrm{h}$; in our experiment we started analyses at $48 \mathrm{~h}$ after $\mathrm{PH}$ and $24 \mathrm{~h}$ after the second dose of IFNa-2b. Moreover, in rats after a first peak

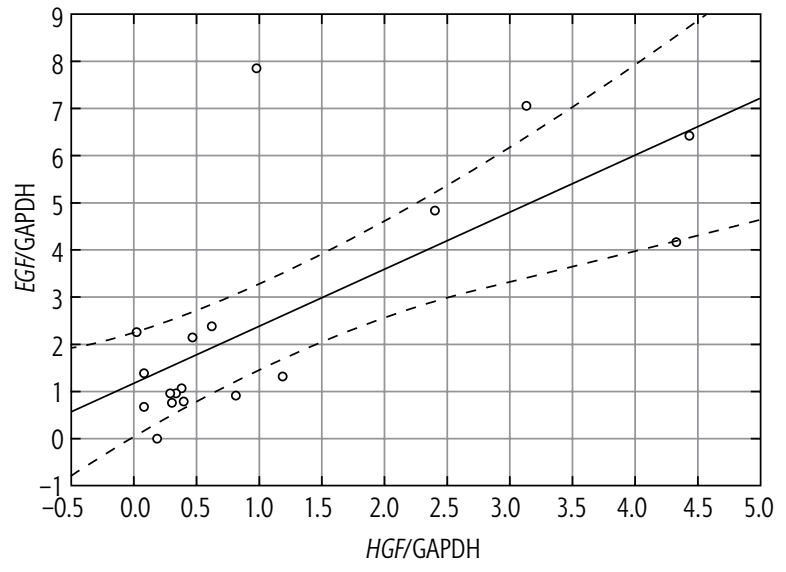

Fig. 2. Correlation between HGF and EGF expression in normal liver tissue $(r=0.713, p=0.001)$

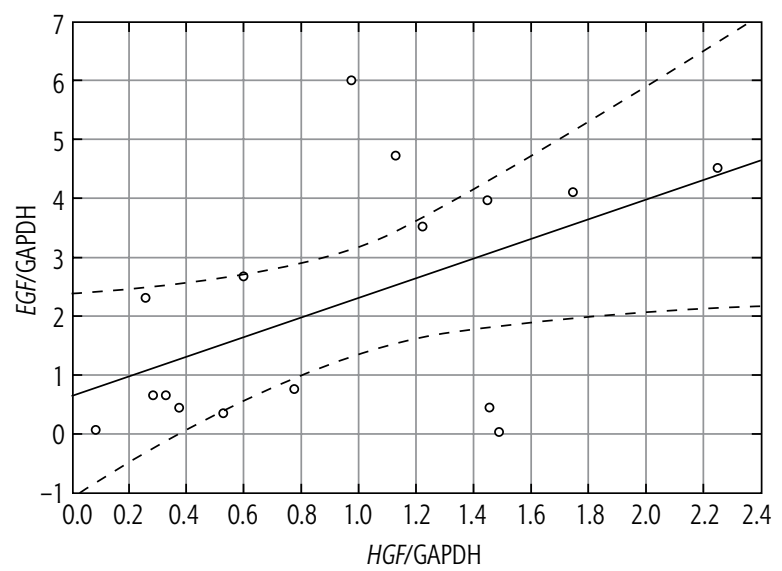

Fig. 3. Correlation between HGF and EGF expression in liver tissue exposed to a single dose of IFN- $\alpha(r=0.52, p=0.038)$

of hepatocyte DNA synthesis, around $24 \mathrm{~h}$ after $\mathrm{PH}$ a second smaller peak is detected between 36 and $48 \mathrm{~h}$ [1] - the time after surgery when IFN $\alpha-2 b$ administered 
$24 \mathrm{~h}$ after $\mathrm{PH}$ could modulate the proliferative phase of regeneration. Li et al. used the Rat Genome 2302.0 Array to determine the expression changes of genes responsible for hepatocyte G0/G1 transition during rat liver regeneration and concluded that the HGF, IL-10, IL-6 and JAK/STAT signaling pathways play a major role [27]. In our study HGF expression was still significantly higher at $48 \mathrm{~h}$ in simply hepatectomized rats and in regenerating liver upon IFNa-2b influence, while no differences were observed in later stages in both groups. The possible explanations are that the administered dose of IFNa-2b was not high enough for HGF expression inhibition or this result reflects the importance of restoring tissue deposits of HGF mRNA in regenerating liver. The liver tissue concentrations of HGF showed no differences at any time point in either experimental group. It could suggest that during liver regeneration the amount of HGF molecules is rather stable in the 48-120 $\mathrm{h}$ period of time and IFNa-2b administration does not influence this status. Unfortunately, the ELISA method does not allow one to distinguish the inactive form of HGF bound in ECM from the biologically active double-chain molecule. It is possible that during regeneration these two forms remain in a dynamic balance in the tissue environment, but this idea needs to be proven.

The experimental data on EGF expression during rat liver regeneration are not unequivocal.

Haber et al. reported undetectable EGF and EGFR gene expression during the immediate-early phase of rat liver regeneration [28]. On the other hand, a rapid increase of EGF mRNA in the immediate-early phase of liver regeneration was also proven [9]. Recent published data of NF- $\mathrm{kB}$ signaling pathway-related gene analyses based on the Rat Genome 2302.0 array made by Chang et al. revealed EGF in the group of genes significantly under-expressed at 12 and $30 \mathrm{~h}$, but there was no differences in its expression during the period of 36-168 hours of liver regeneration. In the same experiment $H G F$ expression was significantly higher at $6 \mathrm{~h}, 24 \mathrm{~h}$ and $30 \mathrm{~h}$, but once more its expression was significant at $72 \mathrm{~h}$ [29]. The observation connected with $E G F$ expression dynamics is consistent with our results only until $96 \mathrm{~h}$, but in our experiment at $120 \mathrm{~h} \mathrm{EGF}$ expression was significantly higher in normal than in regenerating liver but not in tissue exposed to IFNa-2b before. Moreover, their experiment was performed using hepatocytes isolated from regenerating rat livers, while in our study $H G F$ and $E G F$ gene expression was analyzed in tissue samples, where it could be modified by the cellular milieu; moreover, for both factors not only hepatocytes are their important source. Our results of low, but significantly correlated $H G F$ and
EGF expression in normal liver tissue seems to be in concordance with observations reported previously [ 1 , 3-5]. This correlation also exists in liver tissue exposed to one dose of IFNa-2b, but not in later steps of liver regeneration irrespectively of its influence or absence. We tried to established whether these two growth factors have been importantly changing during later stages of liver regeneration at both the mRNA and molecular levels and whether IFNa-2b administration will change it - and if so, when. Based on our results, we conclude that HGF and EGF are not significantly involved in later stages of liver regeneration, and IFNa-2b does not impact their activity in these circumstances.

\section{Conclusions}

Hepatocyte growth factor and EGF are not significantly involved in regulation of later stages of rat liver regeneration. IFN $\alpha-2 b$ does not impact expression of their genes or the presence of these growth factor molecules in regenerating liver tissue.

\section{Disclosure}

Authors report no conflict of interest.

\section{References}

1. Michalopoulos GK, DeFrances MC. Liver regeneration. Science 1997; 276: 60-66.

2. Higgins GM, Anderson RM. Experimental pathology of the liver. I. Restoration of liver of the white rat following partial surgical removal. Arch Pathol 1931; 12: 186-202.

3. Mangnall D, Bird NC, Majeed AW. The molecular physiology of liver regeneration following partial hepatectomy. Liver Int 2003; 23: 124-138.

4. Fausto N, Campbell JS, Riehle KJ. Liver regeneration. Hepatology 2006; 43: 45- 53.

5. Michalopoulos GK. Liver regeneration: molecular mechanisms of growth control. FASEB J 1990; 4: 176-187.

6. van Belle E, Witzenbichler B, Chen D, et al. Potentiated angiogenic effect of scatter factor/hepatocyte growth factor via induction of vascular endothelial growth factor: the case of paracrine amplification of angiogenesis. Circulation 1998; 97: 381-390.

7. Andus T, Bauer J, Gerok W. Effects on cytokines on the liver. Hepatology 1991; 2: 364-375.

8. Natarajan A, Wagner B, Sibilia M. The EGF receptor is required for efficient liver regeneration. Proc Natl Acad Sci U S A 2007; 104: 17081-17086.

9. Stolz DB, Mars WM, Petersen BE, et al. Growth factor signal transduction immediately after two-thirds partial hepatectomy in the rat. Cancer Res 1999; 59: 3954-3960.

10. Mallat A, Preaux A-M, Blazejewski S, et al. Interferon alfa and gamma inhibit proliferation and collagen synthesis of human Ito cells in culture. Hepatology 1995; 21: 1003-1010.

11. Baron S, Tyiring SK, Fleischmann WR, et al. The interferons. Mechanisms of action and clinical applications. JAMA 1991; 266: 13751383. 
12. Platanias LC. Mechanisms of type-I- and type-II-interferonmediated signaling. Nat Rev Immunol 2005; 5: 375-386.

13. Lowry OH, Rosebrough NJ, Farr L, et al. Protein measurement with the Folin phenol reagent. J Biol Chem 1951; 193: 265-275.

14. Nagy P, Teramoto T, Factor VM, et al. Reconstitution of liver mass via cellular hypertrophy in the rat. Hepatology 2001; 33: 339-345.

15. Taub R. Liver regeneration: from myth to mechanism. Nat Rev Mol Cell Biol 2004; 5: 836-847.

16. Zimmermann A. Liver regeneration: the emergence of new pathways. Med Sci Mon 2002; 8: 53-63.

17. Hohmann N, Weiwei W, Dahmen U, et al. How does a single cell know when the liver has reached its correct size? PLoS One 2014; 9, e93207. doi:10.1371/journal.pone.0093207.

18. Mullhaupt B, Feren A, Fodor E, et al. Liver expression of epidermal growth factor RNA. Rapid increase in immediate-early phase of liver regeneration. J Biol Chem 1994; 269: 19667-19670.

19. Pediaditakis P, Lopez-Talavera JC, Petersen B, et al. The processing and utilization of hepatocyte growth factor/scatter factor following partial hepatectomy in the rat. Hepatology 2001; 34 688-693.

20. Lyon M, Deakin JA, Mizuong K, et al. Interaction of hepatocyte growth factor with heparin sulfate. J Biol Chem 1994; 15: 1121611223.

21. Maggiora P, Gambarotta G, Olivero M, et al. Control of invasive growth by the HGF receptor family. J Cell Physiol 1997; 173: 183-186.

22. Mars WM, Liu ML, Kitson RP, et al. Immediate early detection of urokinase receptor after partial hepatectomy and its implications for initiation of liver regeneration. Hepatology 1995; 21 : 1695-1701.

23. Zarnegar R, Michalopoulos GK. The many faces of hepatocyte growth factor: from hepatopoiesis to hematopoiesis. J Cell Biol 1995; 129: 1177-1180.

24. Zarnegar R, DeFrances MC, Kost DP, et al. Expression of hepatocyte growth factor mRNA in regenerating rat liver after partial hepatectomy. Biochem Biophys Res Commun 1991; 177: 559-565.

25. Nishiguchi S, Otani S, Matsui-Yuasa I, et al. Inhibition by interferon (alpha+beta) of mouse liver regeneration and its reversal by putrescine. FEBS Lett 1986; 205: 61-65.

26. Theocharis SE, Margelli AP, Skaltsas SD, et al. Effect of interferon $\alpha 2 \mathrm{~b}$ administration on rat liver regeneration after partial hepatectomy. Dig Dis Sci 1997; 9: 1981-1986.

27. Li M, Zhou X, Mei J, et al. Study on the activity of the signaling pathways regulating hepatocytes from G0 phase into G1 phase during rat liver regeneration. Cell Mol Biol Lett 2014; 19: 181-200.

28. Haber AH, Mohn KL, Diamond RH, et al. Induction patterns of 70 genes during nine days after hepatectomy define the temporary course of liver regeneration. J Clin Invest 1993; 91: 13191326.

29. Chang CF, Mei JX, Zhou Y, et al. Branches of NF-kb signaling pathway regulate hepatocyte proliferation in rat liver regeneration. Genetics and Molecular Research 2015; 14: 7643-7654. 